\title{
Pinus massoniana bark extract inhibits migration of the lung cancer A549 cell line
}

\author{
PING MAO ${ }^{1}$, ERSHAO ZHANG $^{2}$, YANG CHEN ${ }^{2}$, LIKUN LIU $^{2}$, \\ DAQING RONG ${ }^{1}$, QINGFENG LIU ${ }^{1}$ and WEILING $\mathrm{LI}^{2}$ \\ ${ }^{1}$ Department of General Surgery, The People's Hospital of Liaoning Province, Shenyang, Liaoning 110016; \\ ${ }^{2}$ Department of Biotechnology, Dalian Medical University, Dalian, Liaoning 116044, P.R. China
}

Received August 3, 2015; Accepted November 7, 2016

DOI: $10.3892 / \mathrm{ol} .2016 .5509$

\begin{abstract}
The bark of Pinus massoniana is a traditional Chinese medicine for the treatment of various health disorders. Previous studies have demonstrated that $P$. massoniana bark extract (PMBE) may induce the apoptosis of hepatoma and cervical cancer cells. However, whether PMBE is able to inhibit the migration of lung cancer cells requires further investigation. In the current study, the effects of PMBE on the viability of human lung cancer A549 cells were detected using an MTT assay. The migration of lung cancer cells following exposure to PMBE were quantified using wound healing and Transwell assays, respectively. The expression levels of matrix metalloproteinase (MMP)-9 were determined using western blotting. The results revealed that PMBE significantly inhibited the growth of the lung cancer cells. In addition, the wound closure rate and the migration of the lung cancer cells were suppressed by PMBE. Furthermore, the expression levels of MMP-9 were reduced. These findings indicated that PMBE is able to restrict the migration and invasion of lung cancer cells, and that PMBE may serve as a novel therapeutic agent for patients with metastatic lung cancer in the future.
\end{abstract}

\section{Introduction}

Lung cancer is one of the most prevalent types of malignant tumor, with 1.83 million new diagnoses per year worldwide, and is a leading cause of cancer-associated mortality globally $(1,2)$. The morbidity associated with lung cancer also is constantly increasing and threatens human health globally (3). The number of lung cancer-associated mortalities worldwide is expected to grow to up to 3 million by 2035 (4). Due to the difficulty in determining an early diagnosis and the high metastatic potential

Correspondence to: Dr Weiling Li, Department of Biotechnology, Dalian Medical University, 9 Dalian Lvshun South Road West, Dalian, Liaoning 116044, P.R. China

E-mail: liweiling2006@hotmail.com

Key words: Pinus massoniana bark extract, lung cancer, migration, matrix metalloproteinase- 9 of this form of cancer, metastasis develops prior to the diagnosis of lung cancer in the majority of cases. Approximately $90 \%$ of patients with lung cancer succumb to the disease due to tumor metastasis (5). Conventional chemotherapy is often ineffective for patients with metastatic lung cancer and frequently causes toxic side effects. Therefore, the development of novel therapeutic agents for patients with lung cancer is required (6).

Cancer cell migration is necessary for tumor development. Previous studies have revealed that tumor migration and invasion depends on the degradation of the extracellular matrix (ECM), which forms a barrier to tumor invasion $(7,8)$. Matrix metalloproteinases (MMPs) are a large family of zinc-dependent endopeptidases capable of degrading the majority of ECM components $(9,10)$. Overexpression of MMPs is frequently detected in various types of cancer and has been observed to facilitate tumor cell metastasis (11). Therefore, the inhibition of the activities of MMPs in the ECM may prevent the invasion of tumor cells and form the basis for an efficient anticancer therapy.

Pinus massoniana is a tree species native to Southern China (12) and P. massoniana bark extract (PMBE) is an established traditional Chinese medicine used for the treatment of rheumatism, arthralgia, inflammation and cancer $(13,14)$. The primary active component of PMBE is anthocyanin series B (15). Certain studies have reported that PMBE induces the apoptosis of hepatoma and cervical cancer cells $(16,17)$. However, the effects of PMBE on the migration and invasion of lung cancer have yet to be elucidated. In the present study, the effect of PMBE on the migration and invasion of human lung cancer A549 cells was investigated in order to examine the molecular mechanisms underlying this process.

\section{Materials and methods}

Reagents and chemicals. RPMI-1640 medium and fetal bovine serum (FBS) were purchased from Gibco (Thermo Fisher Scientific, Inc., Waltham, MA, USA). Transwells (polyethylene terephthalate; $8.0-\mu \mathrm{m}$ pore size) were purchased from BD Biosciences (San Jose, CA, USA). Antibodies against MMP-9 (catalog no. 10375-2-AP; 1:500 dilution) and $\beta$-actin (catalog no. 60008-1-Ig; 1:2,000 dilution) were obtained from ProteinTech Group, Inc. (Chicago, IL, USA). An enhanced 
chemiluminescence (ECL) kit was purchased from GE Healthcare Life Sciences (Chalfont, UK). MTT was obtained from Ameresco, Inc. (Framingham, MA, USA) and PMBE powder was purchased from Shaanxi Tianrun Pytochemical Co. Ltd. (Shaanxi, China).

Cell culture. The human lung cancer A549 cell line was obtained from the American Type Culture Collection (Manassas, VA, USA) and maintained in RPMI-1640 medium supplemented with $10 \% \mathrm{FBS}$ at $37^{\circ} \mathrm{C}$ in an incubator containing $5 \% \mathrm{CO}_{2}$. The cells were harvested upon reaching $80 \%$ confluency.

MTT assay. The cells were plated in 96-well plates at a density of $1 \times 10^{4} /$ well and incubated for $24 \mathrm{~h}$ at $37^{\circ} \mathrm{C}$. Subsequently, $200 \mu 1$ RPMI-1640 medium containing $0,50,100,150$ or $200 \mu \mathrm{g} / \mathrm{ml}$ PMBE was added to the wells. The cells treated without PMBE served as the control for the MTT assay. The cells were then cultured for $24 \mathrm{~h}$ and incubated with $20 \mu 1 \mathrm{MTT}$ solution $(5 \mathrm{mg} / \mathrm{ml})$ for $4 \mathrm{~h}$ in $5 \% \mathrm{CO}_{2}$ at $37^{\circ} \mathrm{C}$. Subsequently, $150 \mu \mathrm{l}$ dimethyl sulfoxide was added into each well and the absorbance was evaluated at a wavelength of $589 \mathrm{~nm}$ in a Multiskan Ascent plate reader (Thermo Fisher Scientific, Inc.).

Wound healing assay. A549 cells were seeded into 6-well plates at a density of $5 \times 10^{4} / \mathrm{ml}$ and then the cell monolayer was scratched with the end of a $200-\mu 1$ pipette tip. The plates were washed with phosphate-buffered saline to remove detached cells. Subsequently, the cells were treated with 0,25 or $50 \mu \mathrm{g} / \mathrm{ml}$ PMBE solution for $48 \mathrm{~h}$. The cells treated without PMBE served as the control for the wound healing assay. The migration of the lung cancer cells was observed under a phase-contrast microscope (magnification, $\mathrm{x} 40$ ) at 0 and $48 \mathrm{~h}$ post-wounding. The cells that had migrated into the denuded area in each of six random fields were evaluated and quantified using a computer-assisted microscope (Novel, Inc. Ningbo, Zhejiang, China).

Transwell chamber assay. The migration ability of the A549 cells was quantified using a Transwell assay. The A549 cells were treated with 0,25 or $50 \mu \mathrm{g} / \mathrm{ml} \mathrm{PMBE}$ solution for $24 \mathrm{~h}$ at $37^{\circ} \mathrm{C}$. The cells treated without PMBE served as the control for the Transwell chamber assay. A total of $2 \times 10^{5}$ cells in RPMI-1640 medium without serum were added to each upper chamber, and RPMI-1640 supplemented with $10 \%$ FBS was added to the lower chamber as a chemoattractant. After $48 \mathrm{~h}$ of treatment at $37^{\circ} \mathrm{C}$, the cells remaining on the upper surface of the membrane were removed with cotton swabs, and the cells that had migrated to the underside of the membrane were fixed using $4 \%$ paraformaldehyde and stained with $0.1 \%$ crystal violet for $10 \mathrm{~min}$ at room temperature. The migrated cells on the underside of membrane were washed with PBS and counted under a microscope (magnification, x100).

Western blot analysis. The A549 cells were harvested and lysed in cold radioimmunoprecipitation assay buffer. The cells treated without PMBE served as the control group in western blot assay. Total proteins $(20 \mu \mathrm{g})$ were separated by $10 \%$ SDS-PAGE, transferred to nitrocellulose membranes using a semi-dry apparatus for $40 \mathrm{~min}$ and then blocked with

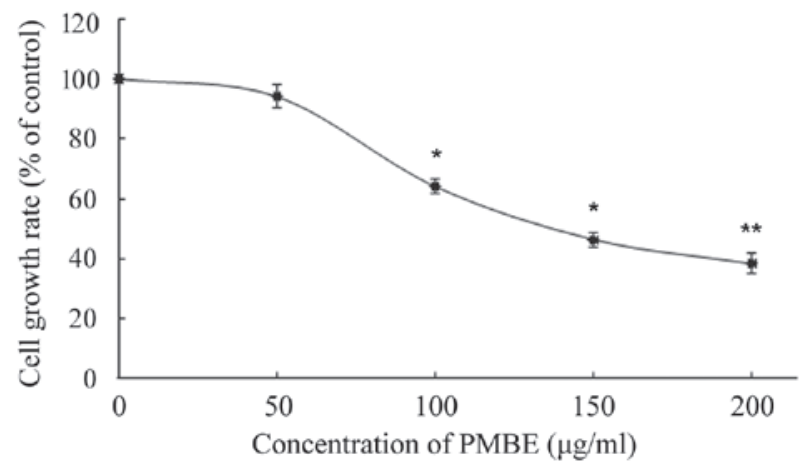

Figure 1. Effect of PMBE on the proliferation of lung cancer A549 cells. The cells were treated with various concentrations of $\operatorname{PMBE}(0,50,100,150$ and $200 \mu \mathrm{g} / \mathrm{ml}$ ) for $24 \mathrm{~h}$. The effects of PMBE on the growth rate of the lung cancer cells were detected using an MTT assay. The experiments were repeated three times. ${ }^{*} \mathrm{P}<0.05$ and ${ }^{* *} \mathrm{P}<0.01$ vs. control group. $\mathrm{PMBE}$, Pinus massoniana bark extract.

blocking buffer (5\% skimmed milk in Tris-buffered saline) for $1.5 \mathrm{~h}$ at room temperature. Specific primary antibodies against MMP-9 (catalog no. 10375-2-AP) and $\beta$-actin (catalog no. 60008-1-Ig) (ProteinTech Group, Inc.) at 1:500 and 1:2,000 dilution, respectively, were added and incubated overnight at $4^{\circ} \mathrm{C}$. Following incubation with corresponding anti-mouse (catalog no. SA00001-1)/rabbit (catalog no. SA00001-2) horseradish peroxidase-conjugated secondary antibodies at 1:2,000 dilution for $2 \mathrm{~h}$ at room temperature, the protein bands were visualized using an enhanced chemiluminescence (ECL) kit (GE Healthcare Life Sciences) by Image Lab 4.0 (Bio-Rad Laboratories, Inc., Hercules, CA, USA). The bands were quantified by Image $\mathbf{J}$ software (National Institutes of Health, Bethesda, MD, USA). $\beta$-actin was used as the loading control.

Statistical analysis. Statistical analyses were performed using SPSS version 13.0 (SPSS Inc., Chicago, IL, USA). The data were presented as the mean \pm standard deviation. One-way analysis of variance with Bonferroni's multiple comparison test was used to compare between the groups. $\mathrm{P}<0.05$ was considered to indicate a statistically significant difference.

\section{Results}

Effects of PMBE on human lung cancer cell proliferation. The A549 cells were treated with various concentrations of PMBE $(0,50,100,150$ and $200 \mu \mathrm{g} / \mathrm{ml})$ for $24 \mathrm{~h}$. The inhibitory effect of PMBE on the lung cancer cells was evaluated using an MTT assay. The results revealed that PMBE exhibited antiproliferative effects on the lung cancer A549 cells. There was a significant dose-dependent decrease in the proliferation of lung cancer cells that were treated with $\mathrm{PMBE}(\mathrm{P}=0.0338, \mathrm{P}=0.0173$ and $\mathrm{P}=0.0024$ for the cells treated with 100,150 and $200 \mu \mathrm{g} / \mathrm{ml}$ PMBE, respectively, compared with the control group). The $\mathrm{IC}_{50}$ value of PMBE was $148 \mu \mathrm{g} / \mathrm{ml}$ for $24 \mathrm{~h}$ (Fig. 1).

Effects of PMBE on human lung cancer cell migration. To investigate whether PMBE is able to affect the migration of lung cancer cells, a wound healing assay was performed. PMBE solution dose-dependently reduced the movement of A549 cells in the wound-healing assay (Fig. 2A). With the increase 
A

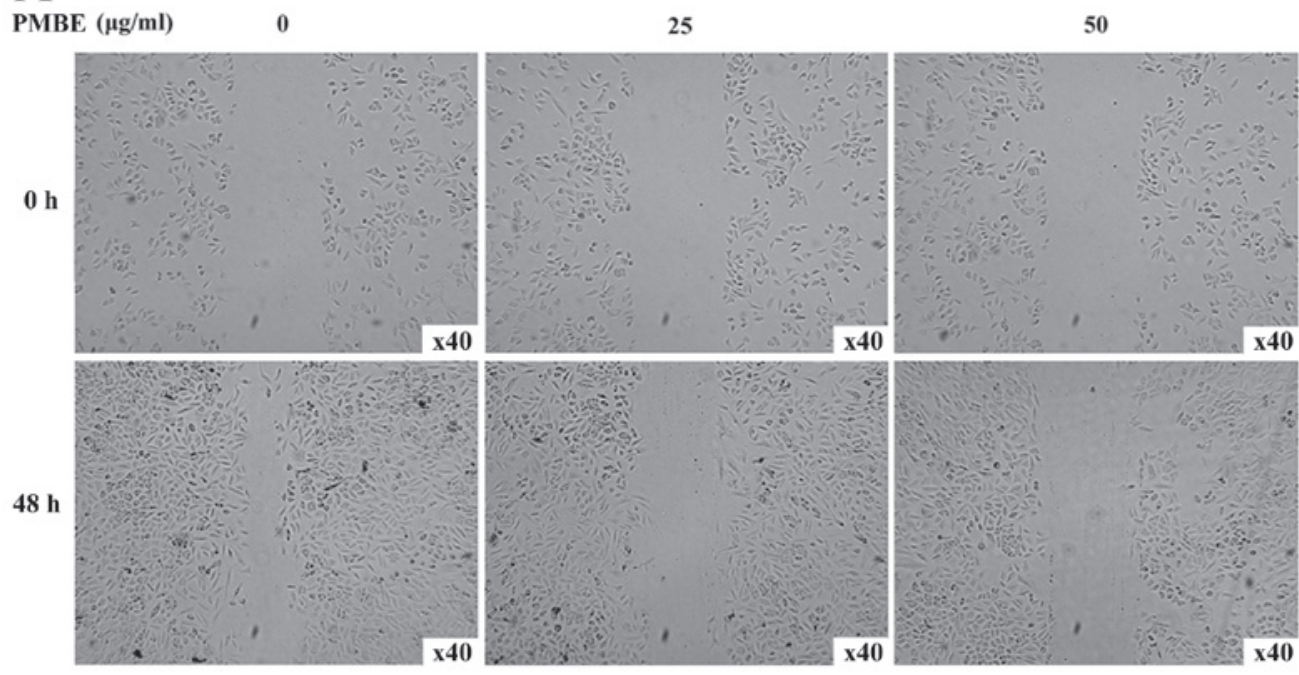

$\mathrm{B}$

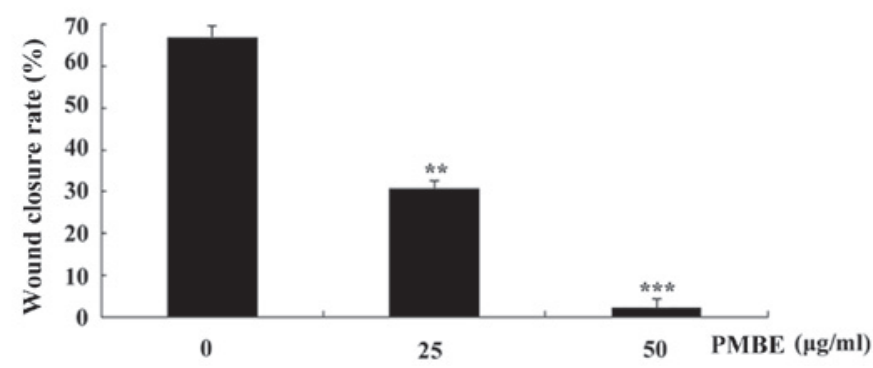

Figure 2. Effect of PMBE on wound healing in lung cancer A549 cells. The cells were scraped with a pipette tip and treated with PMBE $(0,25 \mathrm{and} 50 \mu \mathrm{g} / \mathrm{ml})$ for $48 \mathrm{~h}$. (A) The migration of the cells was observed using a microscope (magnification, $\mathrm{x} 40$ ) prior to and following injury. (B) The migration of the A549 cells was quantified by measuring the wound closure areas pre- and post-injury. The experiments were repeated three times. ${ }^{* *} \mathrm{P}<0.01$ and ${ }^{* * *} \mathrm{P}<0.001$ vs. control group. PMBE, Pinus massoniana bark extract.

in PMBE concentration, the movement of the lung cancer cells was significantly decreased $(\mathrm{P}=0.0081$ and $\mathrm{P}=0.0006$ for the cells treated with 25 and $50 \mu \mathrm{g} / \mathrm{ml} \mathrm{PMBE}$, respectively, compared with the control group). The wound closure/migration rates of the lung cancer A549 cells treated with 0,25 and $50 \mu \mathrm{g} / \mathrm{ml}$ PMBE were 66.67, 30.61 and $2.08 \%$, respectively (Fig. 2B). Therefore, the results of the wound-healing assay suggested that PMBE maybe suppress the migration of lung cancer cells.

Effects of PMBE on human lung cancer cell migration. A Transwell assay was performed to investigate the anti-migration effects of PMBE on lung cancer A549 cells. PMBE inhibited the migration of the lung cancer cells in a dose-dependent manner for $48 \mathrm{~h}$ (Fig. 3A). The number of cells that had migrated to the lower surface of the membrane was significantly reduced compared with the control group (Fig. 3B; $\mathrm{P}=0.0064$ and $\mathrm{P}=0.0028$ for the cells treated with 25 and $50 \mu \mathrm{g} / \mathrm{ml}$ PMBE, respectively, compared with the control group). This result suggested that PMBE is able to suppress the migration of lung cancer cells.

Effects of PMBE on the expression of MMP-9 in lung cancer cells. To further investigate the underlying molecular mechanisms by which PMBE may suppress the migration of lung cancer cells, the expression levels of MMP-9 were examined following PMBE treatment using western blotting. The results revealed that PMBE dose-dependently reduced the expression levels of MMP-9 protein (Fig. 4; $\mathrm{P}=0.0049$, $\mathrm{P}=0.0032$ and $\mathrm{P}=0.0007$ for the cells treated with 25,50 and $100 \mu \mathrm{g} / \mathrm{ml}$ PMBE, respectively, compared with the control group. These data suggested that the inhibitory effect of PMBE on the migration of lung cancer cells may, in part, be due to the downregulation of MMP-9 expression levels.

\section{Discussion}

Metastasis in patients with malignant neoplasms is the leading cause of cancer-associated mortality (18-20). Despite recent advancements, there are limited effective therapies available for patients with metastatic lung cancer due to drug resistance or serious side effects $(21,22)$ Therefore, novel alternative therapies to prevent tumor migration and invasion are required for patients with lung cancer.

Plant-derived therapies have been the subject of a number of studies with regard to their pharmacological effects for the treatment and prevention of cancer, due to their high potency and low toxicity (22-24). PMBE has previously been used in traditional Chinese medicine for patients with cancer $(15,25,26)$. The present study investigated the effect of PMBE on lung cancer cells and the potential mechanisms underlying this process. 
A PMBE

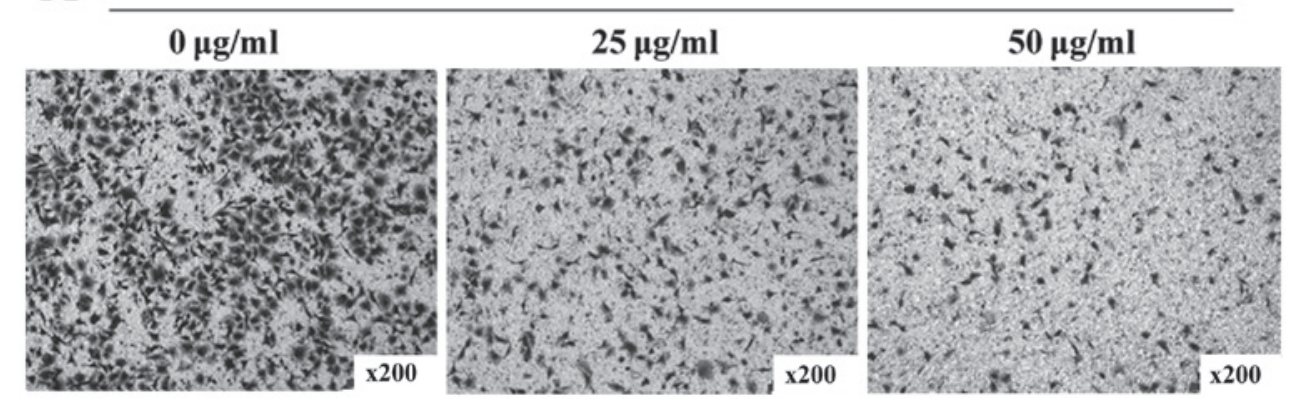

B

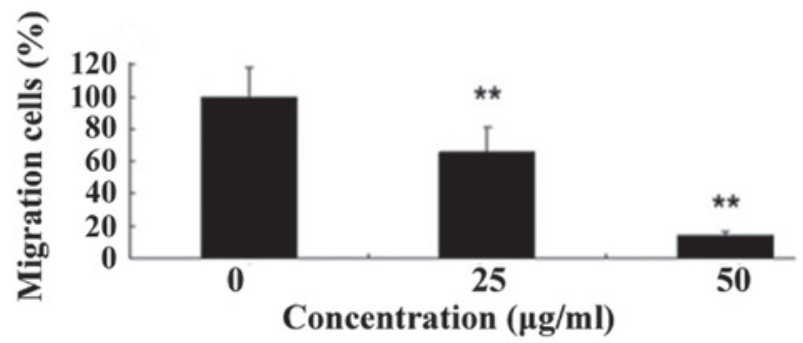

Figure 3. Effect of PMBE on the migration of lung cancer A549 cells. Transwell assays were used to determine the migration of A549 cells treated with PMBE at various concentrations $(0,25$ and $50 \mu \mathrm{g} / \mathrm{ml})$ after $48 \mathrm{~h}$. (A) Images were captured of cell invasion on to the lower surface of the membrane (magnification, $\mathrm{x} 200$ ). (B) The number of cells that had migrated to the lower surface of the membrane was significantly reduced compared with the control group. ${ }^{* *} \mathrm{P}<0.01$ vs. control group. PMBE, Pinus massoniana bark extract.

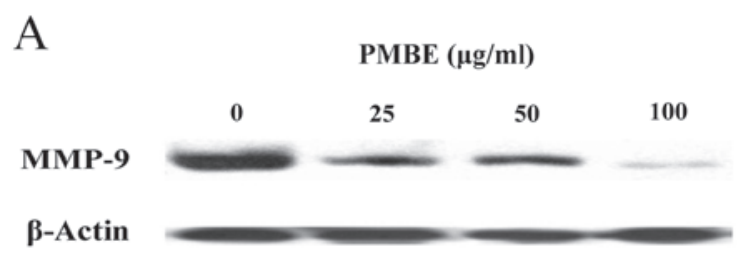

B

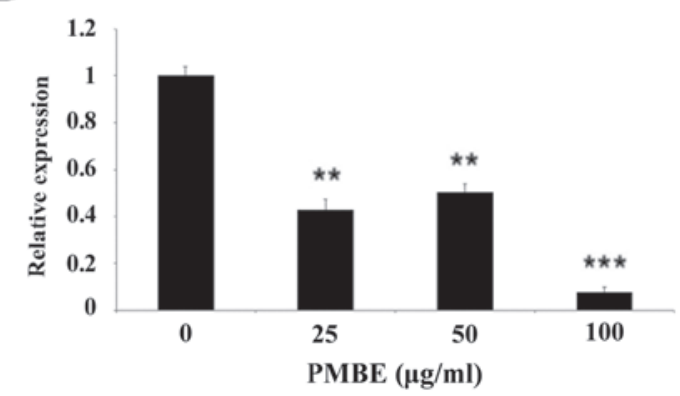

Figure 4. Effects of PMBE on MMP-9 expression levels. Lung cancer A549 cells were treated with $0,25,50$ and $100 \mu \mathrm{g} / \mathrm{ml}$ PMBE for $24 \mathrm{~h}$. Cells treated without PMBE served as the control group. Proteins from the total cell lysate were subjected to western blot analysis to examine the levels of MMP-9 protein. $\beta$-actin was used an internal control. (A) Representative image from three independent experiments is presented. (B) Histogram shows level of MMP-9. MMP-9 levels are expressed relative to the $\beta$-actin loading control and are normalized to the control group. The bands were quantified by Image $\mathrm{J}$ software. ${ }^{* *} \mathrm{P}<0.01$ and ${ }^{* * *} \mathrm{P}<0.001$ vs. control group. PMBE, Pinus massoniana bark extract; MMP-9, matrix metalloproteinase 9.

Firstly, the results of the current study indicated that PMBE was able to significantly prevent the growth of lung cancer cells, and that the cell survival rate was decreased in a dose-dependent manner. A previous study revealed that PMBE exhibits anticancer effects in murine sarcoma S180 cells (25). In addition, PMBE is able to inhibit cell proliferation and induce apoptosis in human hepatoma cells (17). These results suggest that PMBE possesses potential antitumor activity.

Furthermore, the present study demonstrated that PMBE suppressed the migration of lung cancer cells. Further investigation of the molecular mechanisms underlying this process demonstrated that PMBE was able to reduce the expression levels of MMP-9 in the lung cancer cells. MMP-9 is an important member of the MMP family that is used for the degradation of the ECM (27). A previous study revealed that the increased expression of MMP-9 is associated with the development of lung cancer and the promotion of cell metastasis (28). The results of the present study suggested that the effect of PMBE was mediated, at least in part, by the downregulation of MMP-9 expression in the lung cancer cells.

In conclusion, to the best of our knowledge, the current study is the first to indicate that PMBE can inhibit the growth of lung cancer cells. Furthermore, PMBE was able suppress the migration and invasion of the lung cancer cells, which was associated with reduced levels of MMP-9 protein expression. These results suggest that PMBE may be a novel candidate for the treatment of lung cancer.

\section{Acknowledgements}

This study was supported by The Chinese National Natural Science Fund (grant no. 81302282). 


\section{References}

1. Wagland R, Brindle L, Ewings S, James E, Moore M, Rivas C, Esqueda AI and Corner J: Promoting help-seeking in response to symptoms amongst primary care patients at high risk of lung cancer: A mixed method study. PLoS One 11: e0165677, 2016.

2. Biaoxue R, Hua L, Wenlong G and Shuanying Y: Increased serum amyloid $\mathrm{A}$ as potential diagnostic marker for lung cancer: A meta-analysis based on nine studies. BMC Cancer 16: 836, 2016.

3. Amoori N, Mirzaei M and Cheraghi M: Incidence of cancers in Kuzestan province of Iran: Trend from 2004 to 2008. Asian Pac J Cancer Prev 15: 8345-8349, 2014.

4. Didkowska J, Wojciechowska U, Mańczuk M and Łobaszewski J: Lung cancer epidemiology: Contemporary and future challenges worldwide. Ann Transl Med 4: 150, 2016.

5. Prabhu VV and Guruvayoorappan C: Inhibition of metastatic lung cancer in C57BL/6 mice by marine mangrove Rhizophora apiculata. Asian Pac J Cancer Prev 14: 1833-40, 2013.

6. Khozin S, Blumenthal GM, Jiang X, He K, Boyd K, Murgo A, Justice R, Keegan P and Pazdur R: U.S. Food and Drug Administration approval summary: Erlotinib for the first-line treatment of metastatic non-small cell lung cancer with epidermal growth factor receptor exon 19 deletions or exon 21 (L858R) substitution mutations. Oncologist 19: 774-779, 2014.

7. Kurniawan NA, Chaudhuri PK and Lim CT: Concentric Gel System to Study the Biophysical Role of Matrix Microenvironment on 3D Cell Migration. J Vis Exp e52735, 2015.

8. Alfano M, Nebuloni M, Allevi R, Zerbi P, Longhi E, Lucianò R, Locatelli I, Pecoraro A, Indrieri M, Speziali C, et al: Linearized texture of three-dimensional extracellular matrix is mandatory for bladder cancer cell invasion. Sci Rep 6: 36128, 2016.

9. Liu D, Guo H, Li Y, Xu X, Yang K and Bai Y: Association between polymorphisms in the promoter regions of matrix metalloproteinases (MMPs) and risk of cancer metastasis: A meta-analysis. PLoS One 7: e31251, 2012.

10. Huang TH, Chiu YH, Chan YL, Chiu YH, Wang H, Huang KC, $\mathrm{Li}$ TL, Hsu KH and Wu CJ: Prophylactic administration of fucoidan represses cancer metastasis by inhibiting vascular endothelial growth factor (VEGF) and matrix metalloproteinases (MMPs) in lewis tumor-bearing mice. Mar Drugs 13: 1882-1900, 2015.

11. Hassan ZK, Elamin MH, Daghestani MH, Omer SA, Al-Olayan EM, Elobeid MA, Virk P and Mohammed OB: Oleuropein induces anti-metastatic effects in breast cancer. Asian Pac J Cancer Prev 13: 4555-4559, 2012.

12. Ma H, Liu B, Feng D, Xie H, Li R, Yuchi Y, Wang H and Wang J: Pinus massoniana bark extract selectively induces apoptosis in human hepatoma cells, possibly through caspase-dependent pathways. Int J Mol Med 25: 751-759, 2010.

13. Cui Y, Xie H and Wang J: Potential biomedical properties of Pinus massoniana bark extract. Phytother Res 19: 34-38, 2005.

14. Liu J, Bai J, Jiang G, Li X, Wang J, Wu D, Owusu L, Zhang E and Li W: Anti-tumor effect of Pinus massoniana bark proanthocyanidins on ovarian cancer through induction of cell apoptosis and inhibition of cell migration. PLOS One 10: e0142157, 2015.
15. Wang C, Zhang L, Cheng P and Zhang Q: Inhibitory effects of Pinus massoniana bark extract on hepatitis $\mathrm{C}$ virus in vitro. Pharm Biol 53: 451-456, 2015.

16. Ma H, Lai F, Xie H, Wang J and Wang H: Involvement of the Bcl-2 family members in Pinus massoniana bark extract induced apoptosis in HeLa cells. Phytother Res 22: 1472-1476, 2008.

17. Cui YY, Xie H, Qi KB, He YM and Wang JF: Effects of Pinus massoniana bark extract on cell proliferation and apoptosis of human hepatoma BEL-7402 cells. World J Gastroenterol 11: 5277-5282, 2005 .

18. Wan QL, Hou XS and Zhao G: Utility of serum peptidome patterns of esophageal squamous cell carcinoma patients for comprehensive treatment. Asian Pac J Cancer Prev 14: 2919-2923, 2013

19. Liu YC, Zhao J, Hu CE, Gan J, Zhang WH and Huang GJ: Comprehensive analysis of vascular endothelial growth factor-C related factors in stomach cancer. Asian Pac J Cancer Prev 15: 1925-1929, 2014.

20. Qi Y, Li X, Zhao S and Han Y: Value of porous titanium alloy plates for chest wall reconstruction after resection of chest wall tumors. Asian Pac J Cancer Prev 15: 4535-4538, 2014.

21. Pradhan S, Mahajan D, Kaur P, Pandey N, Sharma C and Srivastava T: Scriptaid overcomes hypoxia-induced cisplatin resistance in both wild-type and mutant p53 lung cancer cells. Oncotarget 10.18632/oncotarget: 18632, 2016 (Epub ahead of print).

22. Park KI, Park HS, Kang SR, Nagappan A, Lee DH, Kim JA, Han DY and Kim GS: Korean Scutellaria baicalensis water extract inhibits cell cycle G1/S transition by suppressing cyclin D1 expression and matrix-metalloproteinase-2 activity in human lung cancer cells. J Ethnopharmacol 133: 634-641, 2011.

23. Lin J, Li Q, Chen H, Lin H, Lai Z and Peng J: Hedyotis diffusa willd. extract suppresses proliferation and induces apoptosis via IL-6-inducible STAT3 pathway inactivation in human colorectal cancer cells. Oncol Lett 9: 1962-1970, 2015.

24. Cai Q, Lin J, Wei L, Zhang L, Wang L, Zhan Y, Zeng J, Xu W, Shen A, Hong Z and Peng J: Hedyotis diffusa Willd inhibits colorectal cancer growth in vivo via inhibition of STAT3 signaling pathway. Int J Mol Sci 13: 6117-6128, 2012.

25. Zhang JH, Feng DR, Ma HL, Liu B, Wang HB, Xie H, Li RD and Wang JF: Antitumor effects of Pinus massoniana bark extract in murine sarcoma S180 both in vitro and in vivo. Am J Chin Med 40: 861-875, 2012.

26. Wu DC, Li S, Yang DQ and Cui YY: Effects of Pinus massoniana bark extract on the adhesion and migration capabilities of HeLa cells. Fitoterapia 82: 1202-1205, 2011.

27. Pintha K, Yodkeeree S and Limtrakul P: Proanthocyanidin in red rice inhibits MDA-MB-231 breast cancer cell invasion via the expression control of invasive proteins. Biol Pharm Bull 38: 571-581, 2015.

28. Balla MM, Desai S, Purwar P, Kumar A, Bhandarkar P, Shejul YK, Pramesh CS, Laskar S and Pandey BN: Differential diagnosis of lung cancer, its metastasis and chronic obstructive pulmonary disease based on serum Vegf, Il-8 and MMP-9. Sci Rep 6: 36065, 2016. 